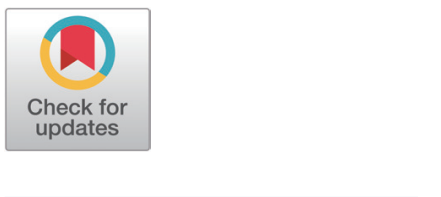

Received: Sep 2, 2021

Revised: Oct 1, 2021

Accepted: Oct 5, 2021

\#These authors contributed equally to this work.

${ }^{*}$ Corresponding author

Hyeun Bum Kim

Department of Animal Resources

Science, Dankook University, Cheonan

31116 , Korea.

Tel: +82-41-550-3653

E-mail: hbkim@dankook.ac.kr

Minho Song

Division of Animal and Dairy Science, Chungnam National University,

Daejeon 34134, Korea

Tel: +82-42-821-5776

E-mail: mhsong@cnu.ac.kr

Copyright () 2021 Korean Society of Animal Sciences and Technology. This is an Open Access article distributed under the terms of the Creative Commons Attribution Non-Commercial License (http:// creativecommons.org/licenses/by$\mathrm{nc} / 4.0 /$ ) which permits unrestricted non-commercial use, distribution, and reproduction in any medium, provided the original work is properly cited.

ORCID

Sheena Kim

https://orcid.org/0000-0002-5410-1347 Jin Ho Cho

https://orcid.org/0000-0001-7151-0778

Hyeun Bum Kim

https://orcid.org/0000-0003-1366-6090

Minho Song

https://orcid.org/0000-0002-4515-5212

Competing interests

No potential conflict of interest relevant to this article was reported.

Funding sources

This work was carried out with the

\section{Evaluation of brown rice to replace corn in weanling pig diet}

\author{
Sheena Kim", Jin Ho Cho ${ }^{2 \#}$, Hyeun Bum Kim ${ }^{1 *}$ and Minho Song ${ }^{3 *}$ \\ ${ }^{1}$ Department of Animal Resources Science, Dankook University, Cheonan 31116, Korea \\ ${ }^{2}$ Division of Food and Animal Science, Chungbuk National University, Cheongju 28644, Korea \\ ${ }^{3}$ Division of Animal and Dairy Science, Chungnam National University, Daejeon 34134, Korea
}

\section{Abstract}

This study was conducted to evaluate the effects of brown rice (Japonica) on growth performance, nutrient digestibility, and blood parameters of weanling pigs. A total of 60 weanling pigs (28-day-old, 30 barrows and 30 gilts, $6.73 \pm 0.77 \mathrm{~kg}$ body weight [BW]) were randomly allotted to 2 dietary treatments ( 6 pigs per pen; 5 replicates per treatment) in a randomized complete block design with the initial BW and sex as blocks. The dietary treatments were a typical nursery diet based on corn and soybean meal (CON) and the CON replaced $50 \%$ of corn with brown rice (BR). Pigs were fed respective dietary treatments for 5 weeks. For the last week of experiment period, pigs were fed respective dietary treatments containing $0.2 \%$ chromic oxide as an indigestible marker. Fecal samples were collected from randomly selected 1 pig in each pen daily for the last $3 \mathrm{~d}$ after the 4-d adjustment period. Blood was collected from randomly selected 1 pig in each pen on $\mathrm{d} 0,3,7$, and 14 after weaning. Compared with pig fed CON diet, pigs fed the BR diet were found to have higher $(p<0.05)$ final BW, overall average daily gain, and apparent ileal digestibility (AID) and apparent total tract digestibility (ATTD) of dry matter and energy. However, there were no significant differences between the groups with respect to average daily feed intake, gain to feed ratio, frequency of diarrhea, and the AID and ATTD of crude protein during overall experimental period. Similarly, there were no significant differences on blood parameters between the groups. Thus, the findings of this study indicate that brown rice (Japonica) can be used to replace $50 \%$ of corn in the diet of pigs during the nursery period without negatively affecting growth performance, nutrient digestibility, or blood parameters.

Keywords: Alternatives, Brown rice, Growth performance, Nutrient digestibility, Weanling pigs

\section{INTRODUCTION}

Given its widespread production and nutritional availability, corn is the main ingredient used as an energy source in swine diet. However, recently corn prices and supply have been fluctuating owing to demand for corn as a raw material for the production of biofuel. Thus, there have been many attempts and efforts to look for alternative ingredients to stable supply and cost-efficiency. Similar to corn, rice is a major source of dietary carbohydrates. However, although rice has a higher starch content compared with other types of cereal [1], given that it tends to be more expensive than corn [2], the use of rice grain as a constituent in animal feed is generally limited, with only certain rice by-products, including 
support of 'Cooperative Research Program for Agriculture Science \& Technology Development (Project No. PJ016227012021)' Rural Development Administration, Korea.

Acknowledgements Not applicable.

Availability of data and material Upon reasonable request, the datasets of this study can be available from the corresponding author.

Authors' contributions Conceptualization: Kim S, Song M. Formal Analysis: Kim S. Methodology: Kim S, Cho JH. Validation: Cho JH, Kim HB. Writing - original draft: Kim S, Cho JH. Writing - review \& editing: Kim HB, Song M.

Ethics approval and consent to participate The protocol used in this experiment was reviewed and approved by Institutional Animal Care and Use Committee of the Chungnam National University, Daejeon, Korea (approval no. CNU-00780). broken rice, rice bran, and rice hull, being routinely used as feedstuffs [3,4].

Although the content of nutrients and bioactive substances varies depending on the degree of the milling, milled rice contains more starch than corn. Furthermore, a previous study has reported that milled rice contains fewer anti-nutritional factors such as non-starch polysaccharides and resistant starch compared to corn, making it easier to digest and reducing the occurrence of diseases such as dysentery [5]. In addition, the endosperm and bran of brown rice are rich in phytochemicals with various physiological activities such as anthocyanins, tocopherols, and polyphenols, so they have high nutritional and physiological value, so they are considered a good substitute for corn in animal feeding $[6,7,8]$. In several countries, including China and the US, previous studies that have assessed the utility of brown rice (Indica) as an effective alternative to corn in animal feed, have indicated that the complete replacement of corn with brown rice in animal diets for weanling and growing pigs does not negatively affect growth performance or the apparent fecal digestibility of nutrients $[7,9,10]$. However, the nutritional composition of rice is dependent on several factors, notably rice subspecies (including Indica and Japonica), climate, soil, and cultivation methods [11]. For example, Indica varieties tend to be less viscous than Japonica, owing to the higher amylose contents of Indica (25\%-30\%) rice compared with those of Japonica (15\%-22\%) [12]. In the present study, we investigated the effects of replacing $50 \%$ of dietary corn with brown rice (Japonica) on growth performance, nutrient digestibility, and blood parameters of weanling pigs.

\section{MATERIALS AND METHODS}

The protocol used in this experiment was reviewed and approved by Institutional Animal Care and Use Committee of the Chungnam National University, Daejeon, Korea (approval no. CNU00780). The experiment was conducted at the Animal Research Center of Chungnam National University, Cheongyang, Korea.

\section{Experimental design, animals, and housing}

A total of 60 weanling pigs (Landrace $\times$ Yorkshire $\times$ Duroc; $6.73 \pm 0.77 \mathrm{~kg}$ of average initial body weight [BW]; 4 weeks of age) were used in this experiment. These pigs were randomly allotted to two dietary treatments (5 pens per treatment and 6 pigs per pen; 3 barrows and 3 gilts) based on a randomized complete block design with BW and sex as blocks. All pigs were housed in an environmentally controlled room, in which each pen was provided with a stainlesssteel feeder and nipple waterers mounted on one side. Room temperature was maintained at $28^{\circ} \mathrm{C}$ for the day of weaning, and then gradually reduced by $2{ }^{\circ} \mathrm{C}$ each week until reaching $22^{\circ} \mathrm{C}$, and therefore maintained at this temperature for remainder of the experiment. Relative humidity was approximately $60 \%$. The lighting program was regulated on a 12 -h light/dark cycle. Throughout the entire experimental period, pigs had ad libitum access to feed and water.

\section{Dietary treatments}

We evaluated the effects of two dietary treatments: (1) a typical weaner pig diet based on corn and soybean meal (CON); and (2) a brown rice diet formulated by replacing $50 \%$ of corn in CON with Japonica brown rice (BR). The replacement level of brown rice was determined based on recommendations made in previous literature [7] and also took into consideration the metabolizable energy (ME) content (Table 1). The pigs were fed the respective diets for 5 weeks.

The experimental diets were formulated to meet or exceed the nutrient requirements of weaner pigs based on the Nutrient Requirements of Swine [13], and had similar crude protein (CP), calcium, and phosphorus levels, although differed with respect to ME. Both diets were provided 
Table 1. Composition of experimental diet for weaner pigs (as-fed basis)

\begin{tabular}{|c|c|c|}
\hline Item $^{1)}$ & CON & $\mathrm{BR}^{2)}$ \\
\hline Ingredient (\%) & 100.00 & 100.00 \\
\hline Corn & 49.86 & 24.93 \\
\hline Brown rice & - & 24.93 \\
\hline Whey powder & 12.50 & 12.50 \\
\hline Soybean meal (44\%) & 25.00 & 25.00 \\
\hline Soy protein concentrate & 6.25 & 6.25 \\
\hline Soybean oil & 3.00 & 3.00 \\
\hline Limestone & 1.14 & 1.14 \\
\hline Monocalcium phosphate & 1.05 & 1.05 \\
\hline Vitamin premix ${ }^{3)}$ & 0.20 & 0.20 \\
\hline Mineral premix ${ }^{4)}$ & 0.20 & 0.20 \\
\hline L-Lys $\cdot \mathrm{HCl}$ & 0.45 & 0.45 \\
\hline DL-Met & 0.16 & 0.16 \\
\hline L-Thr & 0.13 & 0.13 \\
\hline L-Val & 0.06 & 0.06 \\
\hline \multicolumn{3}{|l|}{ Analyzed value } \\
\hline Dry matter (\%) & 95.93 & 95.42 \\
\hline Crude protein (\%) & 22.04 & 22.53 \\
\hline Gross energy (kcal/kg) & 3,988 & 4,112 \\
\hline \multicolumn{3}{|l|}{ Calculated energy and nutrient } \\
\hline Metabolizable energy (kcal/kg) & 3,465 & 3,574 \\
\hline Crude protein (\%) & 21.26 & 21.52 \\
\hline $\mathrm{Ca}(\%)$ & 0.81 & 0.81 \\
\hline $\mathrm{P}(\%)$ & 0.65 & 0.67 \\
\hline Lys (\%) & 1.53 & 1.57 \\
\hline Met (\%) & 0.47 & 0.48 \\
\hline TSAA (\%) & 0.83 & 0.82 \\
\hline $\operatorname{Thr}(\%)$ & 0.95 & 0.97 \\
\hline $\operatorname{Trp}(\%)$ & 0.25 & 0.31 \\
\hline
\end{tabular}

${ }^{1)} \mathrm{CON}$ control diet based on corn and soybean meal, BR replacing corn with $50 \%$ of brown rice.

${ }^{2)}$ Brown rice used in the experiment was Japonica subspecies and had the following analysis values; dry matter $85.5 \%$, crude protein $9.13 \%$, crude fat $2.71 \%$, and ash $1.38 \%$.

${ }^{3)}$ Vitamin premix provided the following quantities of vitamin per kilogram of complete diet: vitamin $A, 12,000 \mathrm{IU}$; vitamin $\mathrm{D}_{3}, 2,500$ $\mathrm{IU}$; vitamin E, $30 \mathrm{IU}$; vitamin $\mathrm{K}_{3}, 3 \mathrm{mg}$; D-pantothenic acid, $15 \mathrm{mg}$; nicotinic acid, $40 \mathrm{mg}$; choline, $400 \mathrm{mg}$; and vitamin $\mathrm{B}_{12}, 12 \mu \mathrm{g}$.

${ }^{4}$ Mineral premix provided the following quantities of mineral per kilogram of complete diet: $\mathrm{Fe}, 90 \mathrm{mg}$ from iron sulfate; Cu, 8.8 $\mathrm{mg}$ from copper sulfate; $\mathrm{Zn}, 100 \mathrm{mg}$ from zinc oxide; Mn, $54 \mathrm{mg}$ from manganese oxide; I, $0.35 \mathrm{mg}$ from potassium iodide; Se, $0.30 \mathrm{mg}$ from sodium selenite.

Lys, lysine; Met, methionine; Thr, threonine; Val, Valine; TSAA, total sulfur amino acids; Trp, tryptophan.

in the form of a mash and were devoid of animal plasma, antibiotics, zinc oxide, and additives to minimize the potential of any adverse physiological or antibacterial effects. Table 1 shows the ingredients and analyzed nutrient compositions of the diets used in this experiment.

\section{Sample and data collection}

Weaner pigs were weighed on day 1 (the first day of the study), and on days 14 and 35 during the experimental period. In order to assess growth performance, we recorded the amounts of feed intake and refusals in each pen to calculate average daily gain (ADG), average daily feed 
intake (ADFI), and the gain to feed ratio (G:F). During the 20 days post-weaning, the amount of diarrhea produced by each pig was monitored daily and the excrement produced was visually assessed by two independent evaluators to provide qualitative scores ranging on a scale from 1 to 5 ( 1 = normal feces, 2 = moist feces, 3 = mild diarrhea, 4 = severe diarrhea, and 5 = watery diarrhea $)$. The frequency of diarrhea was calculated by counting pig days with a diarrhea score of 3 or higher $[14,15]$. On days $1,3,7$, and 14 after weaning, we also collected blood samples from the jugular vein of a single pig selected from each pen for each treatment using vacutainer tubes (Becton Dickinson Vacutainer Systems, Franklin Lakes, NJ, USA) with or without ethylenediaminetetraacetic acid as an anticoagulant [16]. The serum samples were left to clot at room temperature for $2 \mathrm{~h}$, maintained at $4{ }^{\circ} \mathrm{C}$ overnight, and then stored at $-80^{\circ} \mathrm{C}$ after centrifuging for $15 \mathrm{~min}$ at $3,000 \times \mathrm{g}$ at room temperature. At the beginning of the final week of the experimental period, $0.2 \%$ chromic oxide was mixed into each diet as an indigestible marker and the pigs received these modified diets for the duration of the final week of the experimental period [17]. In order to determine the apparent total tract digestibility (ATTD) of nutrients, fecal samples of a randomly selected pig within each pen for each treatment were collected using the anal massage method for three consecutive days after an initial 4-day adaptation period and stored at $-80^{\circ} \mathrm{C}$ until used for analysis. At the end of the experimental period, the selected pigs were euthanized by exposure to $\mathrm{CO}_{2}$ gas subsequent to anesthesia using an intramuscular injection of $50 \mathrm{~mL} / \mathrm{kg}$ BW xylazine [18]. For determinations of the apparent ileal digestibility (AID) of nutrients, digesta samples were immediately collected from the distal ileum anterior to the ileocecal junction and stored at $-80^{\circ} \mathrm{C}$ until used for analysis [19].

\section{Sample analysis}

Frozen fecal and ileal digesta samples were oven-dried at $135^{\circ} \mathrm{C}$ for $2 \mathrm{~h}$ and then finely ground prior to chemical analysis. Samples of the prepared diets, feces, and ileal digesta were analyzed for dry matter (DM; method 930.15), nitrogen (method 988.05) [20], and gross energy (using a bomb calorimeter: Parr 1281 Bomb Calorimeter, Parr Instrument, Moline, IL, USA) contents, and the concentration of $\mathrm{Cr}$ (using an absorption spectrophotometer: Hitachi Z-5000 Absorption Spectrophotometer, Hitachi High-Technologies, Tokyo, Japan) [21]. The AID and ATTD of DM, energy, and $\mathrm{CP}$ were calculated for each sample according to Stein et al. [22]. White blood cell and hematocrit counts were performed using an automated hematology analyzer calibrated for porcine blood (Scil Vet abc hematology analyzer, Scil Animal Care, Altorf, France).

The collected serum was analyzed for total cholesterol, triglycerides, total protein, albumin, blood urea nitrogen, creatinine, calcium, inorganic phosphorus, and magnesium using kits purchased from Wako Pure Chemical Industries (Osaka, Japan) and a clinical auto analyzer (Toshiba Acute Biochemical Analyzer-TBA-40FR, Toshiba Medical Instruments, Tokyo,Japan) [23].

\section{Statistical analysis}

Data were analyzed using the GLM procedure of SAS (SAS Inst, Cary, NC, USA), with pens considered as the experimental unit. The statistical model used for analyses of growth performance, AID and ATTD of nutrients, and blood parameters included the effect of dietary treatments as a fixed effect and initial BW and sex as random effects. The chi-squared test was used for analyzing the frequency of diarrhea production. Normality of data was verified, and outliers were identified for all data. However, no outliers were detected and removed from the dataset. Results are expressed as the mean \pm SEM. Statistical significance and tendency were considered at $p<0.05$ and $0.05 \leq p$ $<0.10$, respectively. 


\section{RESULTS AND DISCUSSION}

\section{Growth performance and nutrient digestibility}

The results obtained for growth performance and nutrient digestibility revealed differences between the two dietary treatments throughout the duration of the experiment (Tables 2 and 3). The current study results showed that compared with weanling pigs fed the CON diet, pigs fed BR diet had higher ADG (487.08 g/d vs. $432.87 \mathrm{~g} / \mathrm{d} ; p<0.01)$ and final BW (23.35 kg vs. $22.04 \mathrm{~kg} ; p<0.05)$. According to Li et al. [7], from week 3 to 4 post-weaning, pigs fed a diet in which corn has either been partially or completely replaced with brown rice tended to be characterized by an increase in ADG and improved feed efficiency compared with those fed an unmodified corn-based diet. Moreover, He et al. [24] mentioned that brown rice would be less palatable compared to corn to piglets during the early weaning stage, but the results of this study agree with Che et al. [25]. and $\mathrm{Li}$ et al. [7], who previously reported that there was no difference in feed intake regardless of the diet treatments over the experimental period. Previous studies have reported that when heat-treated rice is fed to young pigs in the gelatinized form, it is more effective in preventing and reducing the incidence of diarrhea after weaning by reducing the fermented substrate of bacteria compared to heat-treated corn [5]. However, since raw rice was used in this study, it was shown that there was no significant difference in dietary treatment for the incidence of diarrhea in weanling pigs fed the $\mathrm{CON}$ or BR diets during the first 20 days after weaning (Table 2).

The results of nutrient digestibility shown in Table 3 revealed that, compared with weanling pigs fed the CON diet, those received the BR diet had higher $(p<0.05)$ AID of DM $(86.89 \%$ vs. $84.46 \%$ ) and energy (79.93\% vs. $77.05 \%)$. Moreover, weanling pigs fed the BR diet were found to have higher $(p<0.05)$ ATTD of both DM (88.51\% vs. $86.23 \%)$ and energy (86.73\% vs. $84.48 \%)$ than those fed the $\mathrm{CON}$ diet. However, no significant differences were between weaner pigs fed the two experimental diets with respect to the AID and ATTD of CP.The digestibility results obtained

Table 2. Effects of replacing corn with brown rice (Japonica) on growth performance of weaner pigs ${ }^{1)}$

\begin{tabular}{lrrrc}
\hline \multicolumn{1}{c}{ Item ${ }^{2)}$} & CON & \multicolumn{1}{c}{ BR } & SEM & $p$-value \\
\hline Initial BW (kg) & 6.89 & 6.89 & 0.47 & 0.993 \\
Final BW (kg) & 22.04 & 23.35 & 0.56 & $<0.05$ \\
D 1 to 14 & & & & \\
ADG (g/d) & 150.40 & 208.80 & 25.54 & 0.145 \\
ADFI (g/d) & 292.31 & 349.57 & 18.19 & 0.057 \\
G:F (g/g) & 0.50 & 0.59 & 0.07 & 0.363 \\
D 15 to 35 & & & & \\
ADG (g/d) & 621.20 & 672.80 & 19.31 & 0.096 \\
ADFI (g/d) & 915.11 & 929.71 & 37.11 & 0.788 \\
G:F (g/g) & 0.68 & 0.73 & 0.01 & 0.052 \\
D 1 to 35 & & & & \\
ADG (g/d) & 432.87 & 487.08 & 9.41 & 0.01 \\
ADFI (g/d) & 665.99 & 697.65 & 19.17 & 0.277 \\
G:F (g/g) & 0.65 & 0.70 & 0.02 & 0.106 \\
Fecal score (\%) & 3.85 & 3.87 & 0.22 & 0.874 \\
\hline
\end{tabular}

${ }^{1)}$ Each value is the mean of 5 replicates.

${ }^{2)} \mathrm{CON}$, control diet based on corn and soybean meal; BR, replacing corn with $50 \%$ of brown rice.

$B W$, body weight; $A D G$, average daily gain; $A D F I$, average daily feed intake; $G: F$, gain to feed ratio. 
Table 3. Effects of replacing corn with brown rice (Japonica) on apparent ileal digestibility and apparent total tract digestibility of weaner pigs ${ }^{1)}$

\begin{tabular}{lcccc}
\hline \multicolumn{1}{c}{ Item $^{2)}$} & CON & BR & SEM & p-value \\
\hline Apparent ileal digestibility (\%) & & & & \\
$\quad$ Dry matter & 84.46 & 86.89 & 0.83 & $<0.05$ \\
$\quad$ Energy & 77.05 & 79.93 & 0.96 & $<0.05$ \\
$\quad$ Crude protein & 77.23 & 79.41 & 1.03 & 0.312 \\
Apparent total tract digestibility (\%) & & & & \\
$\quad$ Dry matter & 86.23 & 88.51 & 0.77 & $<0.05$ \\
Energy & 84.48 & 86.73 & 0.76 & $<0.05$ \\
$\quad$ Crude protein & 83.47 & 84.65 & 0.91 & 0.714 \\
\hline
\end{tabular}

${ }^{1)}$ Each value is the mean of 5 replicates.

${ }^{2)} \mathrm{CON}$, control diet based on corn and soybean meal; BR, replacing corn with $50 \%$ of brown rice.

in the present study indicate that weanling pigs digest brown rice more easily than corn which is consistent with the findings of previously published research [7,9]. These observations could be attributable to a number of factors. For example, brown rice has a lower fiber content (1.87\%) than corn $(2.86 \%)$, and in this regard, it was reported that fiber could form a physical barrier, thereby limiting the access of amylase to starch granules, and thus inhibiting starch hydrolysis [26]. A high-fiber diet would thus negatively affect the digestible energy value in weaned pigs [27]. However, fiber is not the only factor affecting digestibility. Starch granule size, for example, can also potentially affect the digestibility of energy [28]. The larger the size of starch granules, the smaller is the surface area ratio to volume, which leads to lower enzyme binding, and consequently a reduction in the potential for hydrolysis [29]. Given that the size of starch granules in rice is smaller than that of corn [30]. Pigs fed a diet containing rice might therefore be expected to show a superior digestibility performance compared with those fed a predominantly corn-based diet [2]. Furthermore, Japonica rice has a higher content of amylopectin, which is closely related to the digestibility of grains in pigs [31], and a relatively lower content of amylose than other species. This is because the side chain ( $\alpha$ 1-6 glycosidic bond) constituting amylopectin becomes a weak point for hydrolysis by digestive enzymes and induces it to become a short chain [32].

\section{Hematological and biochemical parameters}

During the initial 2 weeks post-weaning, there were no significant differences between the weanling pigs received the $\mathrm{CON}$ and $\mathrm{BR}$ diets in terms of white blood cell counts, hematocrit, hemoglobin, platelet counts, or mean platelet cell volume (Table 4). The frequency of diarrhea was found to be correlated with the values obtained for hematocrit, also referred to as packed cell volume, which is used as a measure of the mass of red blood cells, and as this can imply dehydration, it is often used as an indicator of animal health [33].

In addition to hematocrit, serum hematological and biochemical parameters are associated with diagnosing pig disease, stress and health status [34]. Furthermore, it was reported that certain hematological parameters, such as hemoglobin, are correlated with the growth rate of pig [35]. In the present study, however, no significant differences were observed between the diets regarding the certain hematological parameters mentioned above. The data from this study were consistent with the normal range for the hematology characteristics in weaned pigs reported by Estienne et al. [36].

Similarly, with the exception of albumin, no significant differences were observed between treatments with respect to any of the assessed serum biochemical parameters (Table 5). These findings are consistent with those of weaned piglets reported by Tumbleson et al. [37] and Cooper 
Table 4. Effects of replacing corn with brown rice (Japonica) on hematological parameters of weaner pigs ${ }^{1)}$

\begin{tabular}{|c|c|c|c|c|}
\hline Item $^{2)}$ & CON & BR & SEM & $p$-value \\
\hline \multicolumn{5}{|l|}{ WBC $\left(10^{3} / \mu \mathrm{L}\right)$} \\
\hline D 1 & 13.4 & 13.4 & 1.5 & 0.979 \\
\hline D 3 & 11.6 & 12.6 & 1.6 & 0.674 \\
\hline D 7 & 16.2 & 19.1 & 0.8 & $<0.05$ \\
\hline D 14 & 23.0 & 19.9 & 2.4 & 0.392 \\
\hline \multicolumn{5}{|l|}{$\operatorname{RBC}\left(10^{6} / \mu \mathrm{L}\right)$} \\
\hline D 1 & 5.6 & 6.0 & 0.2 & 0.218 \\
\hline D 3 & 5.5 & 6.3 & 0.4 & 0.207 \\
\hline D 7 & 6.0 & 6.3 & 0.3 & 0.585 \\
\hline D 14 & 6.3 & 6.3 & 0.3 & 0.988 \\
\hline \multicolumn{5}{|l|}{ HGB (g/dL) } \\
\hline D 1 & 10.2 & 10.6 & 0.45 & 0.603 \\
\hline D 3 & 10.0 & 11.1 & 0.75 & 0.609 \\
\hline D 7 & 11.2 & 11.4 & 0.49 & 0.959 \\
\hline D 14 & 10.3 & 10.3 & 0.32 & 0.784 \\
\hline \multicolumn{5}{|l|}{ HCT (\%) } \\
\hline D 1 & 32.7 & 34.4 & 1.2 & 0.366 \\
\hline D 3 & 32.6 & 35.9 & 2.8 & 0.436 \\
\hline D 7 & 35.3 & 35.6 & 1.5 & 0.886 \\
\hline D 14 & 33.4 & 34.0 & 0.9 & 0.631 \\
\hline \multicolumn{5}{|l|}{$\operatorname{PLT}\left(10^{3} / \mu \mathrm{L}\right)$} \\
\hline D 1 & 453 & 449 & 30.11 & 0.988 \\
\hline D 3 & 466 & 426 & 71.84 & 0.716 \\
\hline D 7 & 362 & 375 & 59.38 & 0.792 \\
\hline D 14 & 398 & 447 & 53.95 & 0.596 \\
\hline \multicolumn{5}{|l|}{$\operatorname{MCV}(f L)^{3)}$} \\
\hline D 1 & 59.0 & 57.4 & 1.15 & 0.630 \\
\hline D 3 & 58.8 & 57.0 & 1.18 & 0.444 \\
\hline D 7 & 59.0 & 56.8 & 1.01 & 0.271 \\
\hline D 14 & 53.0 & 54.0 & 1.33 & 0.796 \\
\hline \multicolumn{5}{|l|}{$\mathrm{MCH}(\mathrm{pg})$} \\
\hline D 1 & 18.4 & 17.8 & 0.4 & 0.342 \\
\hline D 3 & 18.1 & 17.6 & 0.4 & 0.328 \\
\hline D 7 & 18.7 & 18.2 & 0.4 & 0.416 \\
\hline D 14 & 16.4 & 16.4 & 0.3 & 0.966 \\
\hline \multicolumn{5}{|l|}{$\mathrm{MCHC}(\mathrm{g} / \mathrm{dL})$} \\
\hline D 1 & 31.2 & 31.0 & 0.2 & 0.681 \\
\hline D 3 & 30.8 & 30.9 & 0.2 & 0.861 \\
\hline D 7 & 31.8 & 32.0 & 0.1 & 0.269 \\
\hline D 14 & 30.9 & 30.4 & 0.3 & 0.217 \\
\hline
\end{tabular}

${ }^{1)}$ Each value is the mean of 5 replicates.

${ }^{2)} \mathrm{CON}$, control diet based on corn and soybean meal; BR, replacing corn with $50 \%$ of brown rice.

3) fL, femtolitre $\left(10^{-15} \mathrm{~L}\right)$.

WBC, white blood cell; RBC, red blood cell; HGB, hemoglobin; HCT, packed cell volume (Hematocrit); PLT, platelets; MCV, mean corpuscular volume; $\mathrm{MCH}$, mean corpuscular hemoglobin; $\mathrm{MCHC}$, mean corpuscular hemoglobin concentration. 
Table 5. Effects of replacing corn with brown rice (Japonica) on biochemical parameters of weaner pigs ${ }^{1)}$

\begin{tabular}{lrrrc}
\hline \multicolumn{1}{c}{ Item ${ }^{2)}$} & CON & \multicolumn{1}{c}{ BR } & SEM & p-value \\
\hline Total cholesterol (mg/dL) & 82.90 & 69.70 & 5.03 & 0.101 \\
Triglyceride (mg/dL) & 68.80 & 51.90 & 9.97 & 0.265 \\
Total protein (g/dL) & 5.59 & 5.01 & 0.18 & 0.053 \\
Albumin (g/dL) & 3.55 & 3.22 & 0.11 & 0.070 \\
Blood urea nitrogen (mg/dL) & 11.09 & 7.97 & 1.42 & 0.159 \\
Creatinine (mg/dL) & 0.95 & 0.86 & 0.06 & 0.332 \\
Calcium (mg/dL) & 9.54 & 10.86 & 0.80 & 0.222 \\
Inorganic phousphorous (mg/dL) & 8.46 & 9.52 & 0.52 & 0.188 \\
Magnesium (mg/dL) & 2.31 & 2.32 & 0.15 & 0.963 \\
\hline
\end{tabular}

${ }^{1)}$ Each value is the mean of 5 replicates.

${ }^{2)} \mathrm{CON}$, control diet based on corn and soybean meal; BR, replacing corn with $50 \%$ of brown rice.

et al. [38]. And the results of serum biochemical parameters in all pigs in this study were present within the normal range of general pigs of the same age [39].

According to Tao et al. [40], it was reported that the serum biochemical parameters of piglets gradually decreased for one week after weaning, but as a result of this study, it is considered to be recovered to the normal levels after 2 week of weaning. Biochemical parameters are related to nutrient metabolism and utilization [41]. For example, cholesterol and triglycerides are indicators of lipid metabolism [42], and urea nitrogen is an indicator of protein utilization efficiency [43]. Although biochemical parameters are influenced by various factors such as age, sex, and nutrition [38,41], the results of this study showed that replacing corn with rice does not have a negative effect on biochemical parameters.

\section{CONCLUSION}

The findings of the present study indicate that brown rice (Japonica) can be used to replace a substantial proportion of corn in the feed of weanling pigs without negatively affecting growth, digestibility, or blood parameters. Given that, on account of its high starch content, brown rice (Japonica) is a raw material that can contribute to enhancing the rate of energy digestion, and this feed source could provide similar or larger quantities of digestible nutrients to weanling pigs compared with corn.

\section{REFERENCES}

1. Juliano BO. Structure, chemistry, and function of the rice grain and its fractions. Cereal Foods World. 1992;37:772-4.

2. Vicente B, Valencia DG, Pérez-Serrano M, Lázaro R, Mateos GG. The effects of feeding rice in substitution of corn and the degree of starch gelatinization of rice on the digestibility of dietary components and productive performance of young pigs. J Anim Sci. 2008;86:119-26. https://doi.org/10.2527/jas.2006-697

3. Farrell DJ, Hntton K. Rice and rice milling by-products. In: Thacker PA, Kirkwood RN, editors. Nontraditional feed sources for use in swine production. Boston: Butterworth \& Co.; 1990. p. 339-54.

4. Huang B, Shi H, Wang L, Wang L, Lyu Z, Hu Q, et al. Effects of defatted rice bran inclusion level on nutrient digestibility and growth performance of different body weight pigs. Animals. 
2021;11:1374. https://doi.org/10.3390/ani11051374

5. Pluske JR, Siba PM, Pethick DW, Durmic Z, Mullan BP, Hampson DJ. The incidence of swine dysentery in pigs can be reduced by feeding diets that limit the amount of fermentable substrate entering the large intestine. J Nutr. 1996;126:2920-33. https://doi.org/10.1093/ jn/126.11.2920.

6. Ravichanthiran K, Ma ZF, Zhang H, Cao Y, Wang CW, Muhammad S, et al. Phytochemical profile of brown rice and its nutrigenomic implications. Antioxidants. 2018;7:1-16. http://doi. org/10.3390/antiox7060071

7. Li D, Zhang DF, Piao XS, Han IK, Yang CJ, Li JB, et al. Effects of replacing corn with Chinese brown rice on growth performance and apparent fecal digestibility of nutrients in weanling pigs. Asian-Australas J Anim Sci. 2002;15:1191-7. https://doi.org/10.5713/ajas.2002.1191

8. Asyifah MN, Abd-Aziz S, Phang LY, Azlian MN. Brown rice as a potential feedstuff for poultry. J Appl Poult Res. 2012;21:103-10. https://doi.org/10.3382/japr.2011-00379

9. Zhang D, Li D, Piao XS, Han IK, Yang CJ, Shin IS, et al. Effects of replacing corn with brown rice or brown rice with enzyme on growth performance and nutrient digestibility in growing pigs. Asian-Australas J Anim Sci. 2002;15:1334-40. https://doi.org/10.5713/ajas.2002.1334

10. Cromwell GL, Henry BJ, Scott AL, Gerngross MF, Dusek DL, Fletcher DW. Glufosinate herbicide-tolerant (LibertyLink) rice vs. conventional rice in diets for growing-finishing swine. 2005;83:1068-74. https://doi.org/10.2527/2005.8351068x

11. Kim S, Cho JH, Kim HB, Song M. Rice as an alternative feed ingredient in swine diets. J Anim Sci Technol. 2021;63:465-74. https://doi.org/10.5187/jast.2021.e5

12. Liu Q, Wang Z, Chen X, Cai X, Tang S, Yu H, et al. Stable inheritance of the antisense Waxy gene in transgenic rice with reduced amylose level and improved quality. Transgenic Res. 2003;12:71-82. https://doi.org/10.1023/A:1022148824018

13. NRC [National Research Council]. Nutrient requirements of swine. 11th rev. ed. Washington, DC: The National Academies Press; 2012.

14. Park S, Lee JJ, Yang BM, Cho JH, Kim S, Kang J, et al. Dietary protease improves growth performance, nutrient digestibility, and intestinal morphology of weaned pigs. J Anim Sci Technol. 2020;62:21-30. https://doi.org/10.5187/jast.2020.62.1.21

15. Kyoung H, Lee JJ, Cho JH, Choe J, Kang J, Lee H, et al. Dietary glutamic acid modulates immune responses and gut health of weaned pigs. Animals. 2021;11:504. https://doi.org/10.3390/ ani11020504

16. Perri AM, O'Sullivan TL, Harding JCS, Wood RD, Friendship RM. Hematology and biochemistry reference intervals for Ontario commercial nursing pigs close to the time of weaning. Can Vet J. 2017;58:371-6.

17. Kang J, Lee JJ, Cho JH, Choe J, Kyoung H, Kim SH, et al. Effects of dietary inactivated probiotics on growth performance and immune responses of weaned pigs. J Anim Sci Technol. 2021;63:520-30. https://doi.org/10.5187/jast.2021.e44

18. Lee JJ, Kyoung H, Cho JH, Choe J, Kim Y, Liu Y, et al. Dietary yeast cell wall improves growth performance and prevents of diarrhea of weaned pigs by enhancing gut health and anti-inflammatory immune responses. Animals. 2021;11:2269. https://doi.org/10.3390/ani11082269

19. Kim Y, Baek J, Jang K, Kim J, Kim S, Mun D, et al. Effects of dietary enzyme cocktail on growth performance, intestinal morphology, and nutrient digestibility of weaned pigs. Korean J Agric Sci. 2017;44:513-8. https://doi.org/10.7744/kjoas.20170057

20. AOAC [Association of Official Analytical Chemists] International. Official methods of analysis of AOAC International. 18th ed. Gaithersburg, MD: AOAC International; 2005.

21. Williams CH, David DJ, Iismaa O. The determination of chromic oxide in faeces samples by 
atomic absorption spectrophotometry. J Agric Sci. 1962;59:381-5. https://doi.org/10.1017/ S002185960001546X

22. Stein HH, Sève B, Fuller MF, Moughan PJ, De Lange CFM. Invited review: amino acid bioavailability and digestibility in pig feed ingredients: terminology and application. J Anim Sci. 2007;85:172-80. https://doi.org/10.2527/jas.2005-742

23. Wang T, Lee KH, Jung US, Jin YC, Lee SB, Lee JS, et al. Responses of blood metabolites and proteins to different vitamin A levels in Korean native steers. Pak Vet J. 2014;34:527-31.

24. He R, Ma Y, Wang Y, Zhao J, Wang H. Study of the brown rice nutritional value by the pig's digestion and metabolism trial.J Huazhong Agric Univ. 1994;13:268-73.

25. Che TM, Perez VG, Song M, Pettigrew JE. Effect of rice and other cereal grains on growth performance, pig removal, and antibiotic treatment of weaned pigs under commercial conditions.J Anim Sci. 2012;90:4916-24. https://doi.org/10.2527/jas.2011-4916

26. Snow P, O'Dea K. Factors affecting the rate of hydrolysis of starch in food. Am J Clin Nutr. 1981;34:2721-7.https://doi.org/10.1093/ajcn/34.12.2721

27. Stanogias G, Pearcet GR. The digestion of fibre by pigs: 1. the effects of amount and type of fibre on apparent digestibility, nitrogen balance and rate of passage. Br J Nutr. 1985;513-30. https://doi.org/10.1079/BJN19850061

28. Langworthy CF, Deuel J. Digestibility of Starches. 1920;251-61.

29. Singh J, Dartois A, Kaur L. Starch digestibility in food matrix: a review. Trends Food Sci Technol. 2010;21:168-80. https://doi.org/10.1016/j.tifs.2009.12.001

30. Ai Y, Jane J. Chapter 3 - Understanding starch structure and functionality. In: Sjöö M, Nilsson L, editors. Starch in food: structure, function and applications. 2nd ed. Sawston: Woodhead; 2018. p. 151-78.

31. Martens BMJ, Gerrits WJJ, Bruininx EMAM, Schols HA. Amylopectin structure and crystallinity explains variation in digestion kinetics of starches across botanic sources in an in vitro pig model.J Anim Sci Biotechnol. 2018;9:91. https://doi.org/10.1186/s40104-018-0303-8

32. Jane J, Wong K, McPherson AE. Branch-structure difference in starches of A- and B-type X-ray patterns revealed by their naegeli dextrins. Carbohydr Res. 1997;300:219-27. https://doi. org/10.1016/S0008-6215(97)00056-6

33. Buzzard BL, Edwards-Callaway LN, Engle TE, Rozell TG, Dritz SS. Evaluation of blood parameters as an early assessment of health status in nursery pigs. J Swine Health Prod. 2013;21:148-51.

34. Irekhore OT, Adeyemi OM, Idowu OMO, Akinola OS, Bello KO. Growth performance, haematological indices and cost benefits of growing pigs fed cassava peel meal diets supplemented with Allzyme ${ }^{\circledR}$ SSF. Int J Appl Agric Apic Res. 2015;11:51-9.

35. Bhattarai S, Nielsen JP. Association between hematological status at weaning and weight gain post-weaning in piglets. Livest Sci. 2015;182:64-8. https://doi.org/10.1016/j.livsci.2015.10.017

36. Estienne M, Clark-Deener S, Williams K. Growth performance and hematology characteristics in pigs treated with iron at birth and weaning and fed a nursery diet supplemented with a pharmacological level of zinc oxide. J Swine Health Prod. 2019;27:64-75.

37. Tumbleson ME, Kalish PR. Serum biochemical and hematological parameters in crossbred swine from birth through eight weeks of age. Can J Comp Med.1972;36:202-9.

38. Cooper CA, Moraes LE, Murray JD, Owens SD. Hematologic and biochemical reference intervals for specific pathogen free 6-week-old Hampshire-Yorkshire crossbred pigs. J Anim Sci Biotechnol. 2014;5:5. https://doi.org/10.1186/2049-1891-5-5

39. Prvulović D, Jovanović-Galović A, Stanić B, Popović M, Grubor-Lajšić G. Effects of a clinoptilolite supplement in pig diets on performance and serum parameters. Czech J Anim Sci. 
2007;52:159-66. https://doi.org/10.17221/2317-CJAS

40. Tao X, Xu Z, Men X. Transient effects of weaning on the health of newly weaning piglets. Czech J Anim Sci. 2016;61:82-90. https://doi.org/10.17221/8731-CJAS

41. Wu L, Liao P, He Q, Tan B, Guo F, Tang M, et al. Chronic feeding with protein-restricted diets affect ileal amino acid digestibility and the expression of nutrient-sensing, hormone secretion, gastrointestinal digestive enzyme, and nutrient transporter genes in young weaned pigs. Oncotarget. 2018. https://doi.org/10.18632/oncotarget.24093

42. Li YH, Wei HK, Li FN, Kim SW, Wen CY, Duan YH, et al. Regulation in free amino acid profile and protein synthesis pathway of growing pig skeletal muscles by low-protein diets for different time periods.J Anim Sci. 2016;94:5192-205. https://doi.org/10.2527/jas.2016-0917

43. Liu R, He J, Ji X, Zheng W, Yao W. A moderate reduction of dietary crude protein provide comparable growth performance and improve metabolism via changing intestinal microbiota in sushan nursery pigs. Animals. 2021;11:1166. https://doi.org/10.3390/ani11041166 